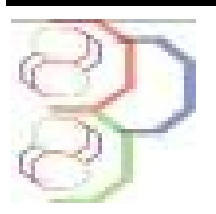

Journal of Applied Biosciences 69:5487 - 5495

\title{
Reproduction of root knot nematode (Meloidogyne incognita) on Bt cotton expressing Cry1Ac and Cry2Ab2 protein
}

\author{
Karuri, H.W., $1,{ }^{*}$ Amata, R., ${ }^{2}$ Amugune, N. ${ }^{3}$ and Waturu, C. 4 \\ ${ }^{1}$ Embu University College, University of Nairobi, P.O Box 6-60100, Embu, Kenya. \\ ${ }^{2}$ National Agricultural Research Laboratories, Kenya Agricultural Research Institute, P.O Box 14733-00800, Nairobi, \\ Kenya. \\ ${ }^{3}$ School of Biological Sciences, University of Nairobi, P.O. Box 30197-00100, Nairobi, Kenya. \\ ${ }^{4}$ Horticultural Research Centre, Kenya Agricultural Research Institute, P.O. Box 220, Thika. \\ "Corresponding author email address: hwkaruri@gmail.com \\ Original submitted in on $10^{\text {th }}$ June 2013 Published online at www.m.elewa.org on $30^{\text {th }}$ September 2013. \\ https://dx.doi.org/10.4314/jab.v69i0.95074
}

\begin{abstract}
Objective: The sedentary endoparasite Meloidogyne incognita is an important plant parasitic nematode that infects cotton causing significant yield losses. The objective of this study was to evaluate reproduction of $M$. incognita in Bt cotton (06Z604D), isoline (99M03) and HART 89M (local non-Bt cotton cultivar) under greenhouse conditions.

Methods and results: Plant height, number of squares/bolls, fresh shoot and root weight were determined before root knot nematode (RKN) screening at 90 and 180 days after planting (DAP). Galling severity, egg mass index, number of juveniles and the presence of Bt protein in roots and soil were also determined. The ELISA detected Bt protein in soil and roots of Bt cotton but not in HART 89M and isoline plant tissues and soil. Reaction of $B t$ cotton and isoline to $M$. incognita was different with the transgenic cotton being more susceptible to RKN. HART 89M was more resistant to RKN infection compared with the isoline.

Conclusion and application of findings: The study has demonstrated that Bt cotton (06Z604D) is susceptible to $M$. Incognita. The results indicate the importance of integrating nematode management practices such as the use of organic amendments and nematicides with other cultural practices in future Kenyan Bt cotton agroecosystems.
\end{abstract}

Keywords: Bacillus thuringiensis, Biosafety, root knot nematode, cotton

\section{INTRODUCTION}

The root knot nematode (RKN) Meloidogyne incognita is an important plant parasitic nematode that infects different plant species causing significant yield losses either through direct feeding of roots or indirectly through interactions with soil borne fungal pathogens. The infective juvenile (IJ) penetrates into the plant through the roots and migrates into the actively dividing plants cells (Srivastava, 1973). The development and reproduction of RKN is dependent on whether or not specialized feeding sites within the vascular tissues are induced. If the host is susceptible, the feeding sites are enlarged resulting in giant cells which arise due to repeated cell divisions. Galling 
occurs due to hypertrophy of cortical cells and within the root galls nematodes continually undergo moulting to the mature female (Jenkins et al., 1995). The changes that occur in the roots include disruption of the root xylem epidermal and cortical tissues development, which in turn affect water and nutrient uptake resulting in stunted growth (Kirkpatrick et al., 1991). Bacillus thuringiensis commercial preparations have been used in the control of plant parasitic nematodes. Sharma (1994) reported 53 to $65 \%$ control of $M$. incognita in barley while Prasad et al. (1972) reported that purified exotoxin was toxic to Meloidogyne larvae and eggs. In other studies, hatching of $M$. javanica was reduced while the mortality was increased after application of Bacillus spp (Dawar, 2008). Application of B. thuringiensis as seed dressing resulted in an increase in seed germination, root length, root weight, shoot length, shoot weight and seed germination (Sheikh et al., 2006). Meloidogyne spp in tomato and okra were also controlled by $B$. thuringiensis (Srivastava, 1973). Tomato and pepper plants had fewer galls and reduced populations of $M$. incognita after application of Bacillus formulations (Zuckerman et al., 1993). Crops have also been genetically engineered for nematode resistance. Li et al. (2007) challenged tomato roots expressing Cry6a protein with $M$. incognita juveniles and compared different infection parameters. $M$. incognita ingested the toxic 54 KDA protein which resulted in a fourfold decrease in reproduction. Phap et al. (2010) reported that Cry1Ab protein in transgenic brinjal resulted in a decrease in the number of galls, egg masses and number of eggs per egg mass. Bt cotton has been evaluated for its reaction

\section{MATERIALS AND METHODS}

The plant material used in the experiment were $\mathrm{Bt}$ cotton (06Z604D), isoline (99M03) and HART 89M (local non Bt cotton cultivar). Bt cotton 06Z604D (Bollgard II) seeds were provided by Monsanto and they were a result of retransformation of Bollgard I which contains Cry1Ac and Neomycin phosphotransferase type II (NPTII) selectable marker protein. In addition, Bollgard II produces beta-Dglucuronidase (GUS) marker protein (Monsanto, 2003). to parasitic nematodes. According to Senthirkumar et al. (2008), there was a significant reduction in nematode and egg production in the reniform nematode populations in Bt cotton. There was a delay in hatching and development to third stage juvenile (J3) in Bt cotton but fourth stage juvenile (J4) showed normal penetration. Colyer et al. (2008) reported that insect resistant cotton was more susceptible to $M$. incognita than nontransgenic cotton. The reason for the observed responses of Bt cotton to the parasitic nematodes may be due to the effect of Bt protein or changes in the plant makeup as a consequence of gene insertion. Different studies have shown that various genes are involved in feeding sites formation and resistance of crops to nematode infection. Meloidogyne induced cotton 3 (MIC 3) resistance genes in cotton do not affect RKN penetration into roots but they prevent the development of the juvenile into adults. The juveniles develop only to J4 stage and they do not form giant cells (Jenkins et al., 1995). In resistant genotypes the $\mathrm{J} 1$ fails to establish and maintain a feeding site and those juveniles that are able to form a feeding site have a slower development process (Wubben et al., 2008). The MIC gene family is involved in defence mechanisms in cotton and it is independent of lipid peroxidation and gossypol biosynthesis.

Bt cotton expressing Cry1Ac and Cry2Ab2 may react differently to infection with $M$. incognita compared with the conventional cultivars due to direct effects of the Cry proteins on the nematodes or indirectly due to pleiotropic effects. The objective of this study was therefore to evaluate RKN reproduction in Bt cotton and its isogenic counterpart.

Comparisons were made between Bt cotton and its isogenic counterpart to test the effect of the Bt gene while HART 89M was compared with isoline to test for any varietal effects.

Pots were filled with $20 \mathrm{~kg}$ sterile soil (sand: loam, 1:1). The soil in each pot was infested with $6000 \mathrm{M}$. incognita eggs and/or juveniles collected from stock cultures of $M$. incognita maintained on tomato (Lycopersicon esculentum). Inoculum was prepared by 
washing the infected tomato roots and chopping them into $2 \mathrm{~cm}$ segments. The galled root segments were processed in $0.05 \%$ Sodium Hypochlorite by agitated extraction. Eggs were then rinsed thoroughly and placed in a water suspension. Ten milliliters of the egg suspension containing the appropriate number of eggs and juveniles was pipetted onto the soil surface in each pot and incorporated into the soil. Pots without $M$. incognita eggs/juveniles served as controls. Two seeds of the appropriate cultivar were planted into each pot immediately after infestation of the soil with the nematodes. Treatments were arranged in the greenhouse in a completely randomized design and replicated four times with each replicate consisting of 12 plants in separate pots. Seven days after planting, pots were thinned to one seedling per pot. Plant height and number of squares/bolls was determined before RKN screening at 90 and 180 days after planting (DAP). Data on fresh shoot and root weight was also recorded at 90 and 180DAP. The experiment was repeated once.

Galling severity per plant was rated according to the following scale: $0=$ no galls; $1=1$ to 2 galls; $2=3$ to 10 galls; $3=11$ to 30 galls; $4=31$ to 100 galls; $5=>100$ galls per root system (Colyer et al., 2008). Egg masses were stained using phloxine B (Holbrook et al., 1983) and rated using a scale of $0-5$ where, $0=$ no egg masses, $1=1-2,2=3-10,3=11-30,4=31-100$, and $5=$ $>100$ egg masses per root system (Kirkpatrick et al., 1991). The number of juveniles in soil was determined at the end of the experiment by taking $200 \mathrm{~cm}^{3}$ of soil from all the treatments and extracting the nematodes using the Whitehead and Hemming (1965) tray method.

\section{RESULTS}

Reaction of $\mathrm{Bt}$ cotton and isoline to $M$. incognita was different with the transgenic cotton being more susceptible to RKN in two greenhouse trials (Table 1, 2, 3 and 4). Plant growth parameters in both treatments were negatively affected by infection with $M$. incognita at 90 and 180DAP. Reduction in growth parameters was apparent at 90 and 180DAP. However, fresh root weight in isoline increased at 180DAP in both trials. The number of juveniles, galling and egg mass index were higher in Bt cotton than in isoline and the values were greater at 180DAP. There was a greater reduction in number of bolls in Bt cotton than in isoline. There were significant month*treatment interactions in both trials for
Rhizosphere soil and roots from Bt cotton, HART 89M and isoline treatments were collected at 90 and 180 DAP. One gram each of soil sample was used for analysis of $\mathrm{Bt}$ protein using the enzyme-linked immunosorbent assay (ELISA). A qualiplate combo kit for Cry1A and Cry2A (AP 051) (EnviroLogix, Portland,

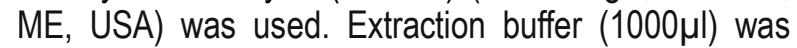
added and vortexed for one minute. For plant samples, $0.5 \mathrm{~g}$ was snap frozen and ground in $1 \mathrm{ml}$ of extraction buffer. Extraction was allowed to take place overnight at $4^{\circ} \mathrm{C}$. Quantification of Cry $2 \mathrm{Ab} 2$ and Cry $1 \mathrm{Ac}$ was determined using a spectrophotometer (Benchmark®, Bio-Rad, Hercules, CA).

Treatment effects on different growth parameters were determined using ANOVA (GenStat 12.1). Means were separated using Fischer's least significant difference test. Differences at $\mathrm{P}<0.05$ level were considered statistically significant. The ELISA results were interpreted according to the manufacturer's protocol where the mean optical density (OD) of the blank wells in the Cry1Ac and Cry2Ab part of the test was such that it did not exceed 0.15 and 0.35 respectively. The mean, blank-subtracted OD of the positive control wells was at least 0.2 and the coefficient of variance (CV) between the duplicate positive control wells did not exceed $15 \%$. The positive control ratio was calculated by dividing the $O D$ of each sample extract by the mean $O D$ of the positive control wells. For Cry2Ab, if the positive control ratio calculated for a sample was less than 1.0 , the sample did not contain Cry2Ab. In the Cry1Ac part of the test if the positive control ratio was less than 0.5 , the sample did not contain the protein. Results are reported as absence or presence of Bt protein.

plant height $\left.\left(F=289.9_{[3,} 21\right] ; \quad P<0.001 ; \quad F=24.9_{[3,} \quad 21\right]$; $P<0.001)$, fresh root weight $(F=220.2[3,21] ; P<0.001$, trial 2), fresh shoot weight $\left(F=26.9_{[3,21] ;} P<0.001 ; F=104.4_{[3}\right.$, 21]; $P<0.001)$, egg mass index $\left(F=71.5_{[1,9]} ; P<0.001\right.$, trial 1), galling index ( $F=51.9_{[1,9] ;} P<0.001 ; F=9.4_{[1,9]}$; $P=0.01)$ and number of juveniles ( $F=88.7_{[1,9] ;} P<0.001$; $\left.F=98.9_{[1,9] ;} P<0.001\right)$. There were significant differences in the number of squares $\left(F=762.9_{[3,9] ;} P<0.001\right.$; $\left.F=472.6_{[3,9] ;} P<0.001\right)$ and number of bolls $\left(F=1952_{[3}\right.$, 9]; $\left.P<0.001 ; F=161.6_{[3,9]} ; P<0.001\right)$ between Bt cotton and isoline at 90 and 180DAP. A decrease in number of bolls in both treatments was recorded at 180DAP. 
Table 1: Effect of Meloidogyne incognita inoculations on plant growth of Bt cotton and its isoline (Trial 1)

\begin{tabular}{lcccccc}
\hline Time & Treatment & $\begin{array}{c}\text { Plant height } \\
(\mathbf{c m})\end{array}$ & $\begin{array}{c}\text { No of } \\
\text { squares }\end{array}$ & No of bolls & $\begin{array}{c}\text { Fresh shoot } \\
\text { weight } \mathbf{( g )}\end{array}$ & Fresh root weight (g) \\
\hline 90DAP & Control Bt cotton & $45.1 \mathrm{~b}$ & $2.5 \mathrm{a}$ & Not collected & $42.1 \mathrm{bc}$ & $6.7 \mathrm{a}$ \\
& Control isoline & $48.7 \mathrm{~d}$ & $5.9 \mathrm{c}$ & Not collected & $43.7 \mathrm{c}$ & $6.6 \mathrm{a}$ \\
& Bt cotton & $38.5 \mathrm{a}$ & $2.5 \mathrm{a}$ & Not collected & $28.7 \mathrm{a}$ & $5.3 \mathrm{~b}$ \\
& Isoline & $45.9 \mathrm{~b}$ & $4.0 \mathrm{~b}$ & Not collected & $39.2 \mathrm{~b}$ & $6.7 \mathrm{a}$ \\
180DAP & Control Bt cotton & $64.3 \mathrm{~g}$ & Not collected & $17.99 \mathrm{~d}$ & $86.3 \mathrm{f}$ & $10.0 \mathrm{c}$ \\
& Control isoline & $61.5 \mathrm{f}$ & Not collected & $14.9 \mathrm{c}$ & $84.5 \mathrm{f}$ & $9.5 \mathrm{e}$ \\
& Bt cotton & $52.8 \mathrm{e}$ & Not collected & $9.12 \mathrm{~b}$ & $53.4 \mathrm{~d}$ & $9.0 \mathrm{~d}$ \\
& Isoline & $46.8 \mathrm{c}$ & Not collected & $8.65 \mathrm{a}$ & $63.5 \mathrm{e}$ & $10.5 \mathrm{f}$ \\
SEM & & 0.23 & 0.05 & 0.1 & 1.01 & 0.17 \\
\hline
\end{tabular}

Means within the same column with the same letter are not different $(P<0.05)$ according to least significant difference test (LSD).

Table 2: Number of Meloidogyne incognita juveniles, egg mass and galling index of Bt cotton and its isoline (Trial 1)

\begin{tabular}{lcccc}
\hline Time & Treatment & aGalling index & ${ }^{\text {b Egg mass index }}$ & No of juveniles $\left(\mathbf{2 0 0 \mathbf { c m } ^ { 3 } )}\right.$ \\
\hline 90DAP & Bt cotton & $2.5 \mathrm{~b}$ & $2.4 \mathrm{~b}$ & $201.6 \mathrm{~b}$ \\
& Isoline & $1.9 \mathrm{a}$ & $2.0 \mathrm{a}$ & $167.9 \mathrm{a}$ \\
\multirow{2}{*}{ 180DAP } & Bt cotton & $4.0 \mathrm{c}$ & $4.0 \mathrm{c}$ & $349.0 \mathrm{~d}$ \\
& Isoline & $2.5 \mathrm{~b}$ & $2.6 \mathrm{~b}$ & $270.6 \mathrm{c}$ \\
SEM & & 0.05 & 0.04 & 1.68
\end{tabular}

Means within the same column with the same letter are not different $(P<0.05)$ according to least significant difference test (LSD).

aBased on a $0-5$ scale, where $0=$ no galls; $1=1$ to 2 galls; $2=3$ to 10 galls; $3=11$ to 30 galls; $4=31$ to 100 galls; $5=>100$ galls per root system (Colyer et al., 2008).

${ }^{\mathrm{b} B a s e d}$ on a $0-5$ scale, where, $0=$ no egg masses, $1=1-2,2=3-10,3=11-30,4=31-100$, and $5=>100$ egg masses per root system (Kirkpatrick et al., 1991).

Table 3: Effect of Meloidogyne incognita inoculations on plant growth of Bt cotton and its isoline (Trial 2)

\begin{tabular}{ccccccc}
\hline Time & Treatment & Plant height $(\mathrm{cm})$ & No of squares & No of bolls & $\begin{array}{c}\text { Fresh shoot } \\
\text { weight }(\mathrm{g})\end{array}$ & $\begin{array}{c}\text { Fresh root } \\
\text { weight }(\mathrm{g})\end{array}$ \\
\hline 90DAP & Control Bt cotton & $46.5 \mathrm{c}$ & $4.4 \mathrm{c}$ & Not collected & $47.3 \mathrm{a}$ & $7.1 \mathrm{a}$ \\
& Control isoline & $48.9 \mathrm{~d}$ & $4.5 \mathrm{c}$ & Not collected & $49.0 \mathrm{a}$ & $10.8 \mathrm{~d}$ \\
& Bt cotton & $33.4 \mathrm{a}$ & $2.1 \mathrm{a}$ & Not collected & $45.5 \mathrm{a}$ & $6.8 \mathrm{a}$ \\
& Isoline & $34.9 \mathrm{~b}$ & $2.4 \mathrm{~b}$ & Not collected & $48.3 \mathrm{a}$ & $8.1 \mathrm{~b}$ \\
180DAP & Control Bt cotton & $62.0 \mathrm{f}$ & Not collected & $16 \mathrm{c}$ & $112.1 \mathrm{e}$ & $14.0 \mathrm{e}$ \\
& Control isoline & $61.7 \mathrm{f}$ & Not collected & $13.51 \mathrm{~b}$ & $85.3 \mathrm{~d}$ & $10.3 \mathrm{c}$ \\
& Bt cotton & $51.1 \mathrm{e}$ & Not collected & $10.54 \mathrm{a}$ & $63.6 \mathrm{~b}$ & $7.8 \mathrm{~b}$ \\
& Isoline & $46.9 \mathrm{c}$ & Not collected & $10.34 \mathrm{a}$ & $75.7 \mathrm{c}$ & $10.7 \mathrm{~cd}$ \\
SEM & & 0.37 & 0.06 & 0.21 & 1.39 & 0.21 \\
\hline
\end{tabular}


Means within the same column with the same letter are not different $(P<0.05)$ according to least significant difference test (LSD).

Table 4: Number of Meloidogyne incognita juveniles, egg mass and galling index of Bt cotton and its isoline (Trial 2)

\begin{tabular}{lllll} 
Time & Treatment & aGalling index & bEgg mass index & No of juveniles $\left(\mathbf{2 0 0 \mathbf { c m } ^ { 3 } )}\right.$ \\
\hline 90DAP & Bt cotton & $2.4 \mathrm{~b}$ & $2.5 \mathrm{a}$ & $176.7 \mathrm{~b}$ \\
& Isoline & $1.4 \mathrm{a}$ & $1.5 \mathrm{c}$ & $121.8 \mathrm{a}$ \\
\multirow{2}{*}{ 180DAP } & Bt cotton & $4.5 \mathrm{~d}$ & $4.5 \mathrm{~b}$ & $415.4 \mathrm{~d}$ \\
& Isoline & $3.0 \mathrm{c}$ & $3.5 \mathrm{~d}$ & $312.8 \mathrm{c}$ \\
SEM & & 0.07 & 0.05 & 2.39 \\
\hline
\end{tabular}

Means within the same column with the same letter are not different $(P<0.05)$ according to least significant difference test (LSD).

aBased on a $0-5$ scale, where $0=$ no galls; $1=1$ to 2 galls; $2=3$ to 10 galls; $3=11$ to 30 galls; $4=31$ to 100 galls; $5=>100$ galls per root system (Colyer et al., 2008).

'Based on a $0-5$ scale, where, $0=$ no egg masses, $1=1-2,2=3-10,3=11-30,4=31-100$, and $5=>100$ egg masses per root system (Kirkpatrick et al., 1991).

Isoline and HART 89M also reacted differently to $M$. incognita infection, with isoline being more susceptible in two greenhouse trials (Table 5, 6, 7and 8). A reduction in growth parameters was observed for both treatments. Significant month*treatment interactions were recorded in both trials for plant height $\left(\mathrm{F}=33.7_{[3}\right.$ 21]; $\left.P<0.001 ; F=13.1_{[3,21]} ; P<0.001\right)$, fresh shoot weight $\left(F=349.7_{[3,21] ;} P<0.001 ; F=64.3_{[3,21]} ; P<0.001\right)$, fresh root weight $\left(F=141.2[3,21] ; P<0.001 ; F=71.7_{[3,21]}\right.$; $P<0.001)$, number of juveniles $(F=7.7[1,9] ; P=0.02$; $\left.F=48.5_{[1,9]} ; P<0.001\right)$, egg mass $\left(F=120.8_{[1,9]} ; P<0.001\right)$ and galling index $\left(F=_{[1,}\right.$ g]; $\left.P=0.005\right)$. There were significant differences in the number of squares ( $\left.F=979.5_{[3,9] ;} P<0.001 ; \quad F=1110_{[3,9]} ; P<0.001\right)$ and number of bolls ( $F=556.1_{[3,9]} ; P<0.001 ; F=79.9_{[3,9]}$; $P<0.001)$ between isoline and HART $89 \mathrm{M}$ at 90 and 180DAP. The qualitative ELISA detected Bt protein in roots of Bt cotton at 90 and 180DAP in both trials. The protein was detected in soil at 180DAP in both trials. No Bt protein was detected in HART 89M and isoline plant tissues and soil.

Table 5: Effect of Meloidogyne incognita inoculations on plant growth of isoline and HART 89M (Trial 1)

\begin{tabular}{llccccc}
\hline Time & Treatment & Plant height & $\begin{array}{c}\text { No of } \\
\text { squares }\end{array}$ & No of bolls & $\begin{array}{c}\text { Fresh shoot weight } \\
\text { (g) }\end{array}$ & $\begin{array}{c}\text { Fresh root weight } \\
\text { (g) }\end{array}$ \\
\hline 90DAP & Control isoline & $48.7 \mathrm{c}$ & $6.0 \mathrm{~d}$ & Not collected & $43.8 \mathrm{~b}$ & $6.5 \mathrm{a}$ \\
& & & & & & \\
& Control HART 89M & $50.2 \mathrm{~d}$ & $2.0 \mathrm{~b}$ & Not collected & $44.4 \mathrm{~b}$ & $7.6 \mathrm{~b}$ \\
& Isoline & $45.9 \mathrm{~b}$ & $4.1 \mathrm{c}$ & Not collected & $39.2 \mathrm{a}$ & $6.7 \mathrm{a}$ \\
& HART 89M & $35.1 \mathrm{a}$ & $0.9 \mathrm{a}$ & Not collected & $37.9 \mathrm{a}$ & $6.8 \mathrm{ab}$ \\
180DAP & Control isoline & $61.5 \mathrm{f}$ & Not collected & $14.9 \mathrm{c}$ & $84.6 \mathrm{~d}$ & $9.5 \mathrm{c}$ \\
& & & & & & \\
& Control HART 89M & $71.9 \mathrm{~g}$ & Not collected & $12.7 \mathrm{~b}$ & $143.5 \mathrm{f}$ & $18.9 \mathrm{f}$ \\
& Isoline & $46.9 \mathrm{~b}$ & Not collected & $8.7 \mathrm{a}$ & $63.5 \mathrm{c}$ & $10.5 \mathrm{~d}$ \\
& HART 89M & $58.9 \mathrm{e}$ & Not collected & $8.9 \mathrm{a}$ & $125.4 \mathrm{e}$ & $18.1 \mathrm{e}$ \\
SEM & 0.41 & 0.07 & 0.13 & 1.36 & 0.27 \\
\hline
\end{tabular}


Table 6: Number of Meloidogyne incognita juveniles, egg mass and galling index of isoline and HART 89M (Trial 1)

\begin{tabular}{llccc} 
Time & Treatment & Galling index & Egg mass index & No of juveniles $\left(\mathbf{2 0 0 \mathbf { c m } ^ { 3 } )}\right.$ \\
\hline 90DAP & Isoline & $1.9 \mathrm{a}$ & $2.0 \mathrm{a}$ & $167.9 \mathrm{~b}$ \\
& HART 89M & $2.0 \mathrm{a}$ & $2.0 \mathrm{a}$ & $144.4 \mathrm{a}$ \\
\multirow{3}{*}{ 180DAP } & Isoline & $2.5 \mathrm{c}$ & $2.6 \mathrm{c}$ & $270.6 \mathrm{~d}$ \\
& HART 89M & $2.4 \mathrm{~b}$ & $2.5 \mathrm{~b}$ & $234.7 \mathrm{c}$ \\
SEM & & 0.06 & 0.11 & 2.22 \\
\hline
\end{tabular}

Table 7: Effect of Meloidogyne incognita inoculations on plant growth of isoline and HART 89M (Trial 2)

\begin{tabular}{llccccc}
\hline Time & Treatment & Plant height & No of squares & No of bolls & (g) & (g) \\
\hline 90DAP & Control isoline & $49.0 \mathrm{~d}$ & $4.5 \mathrm{~d}$ & Not collected & $49.0 \mathrm{a}$ & $10.8 \mathrm{c}$ \\
& Control HART & & & & & \\
& 89M & $57.3 \mathrm{e}$ & $1.5 \mathrm{~b}$ & Not collected & $54.4 \mathrm{a}$ & $8.5 \mathrm{~b}$ \\
& Isoline & $34.9 \mathrm{a}$ & $2.4 \mathrm{c}$ & Not collected & $48.3 \mathrm{a}$ & $8.1 \mathrm{~b}$ \\
& HART 89M & $43.9 \mathrm{~b}$ & $1 \mathrm{a}$ & Not collected & $52.5 \mathrm{a}$ & $6.9 \mathrm{a}$ \\
180DAP Control isoline & $61.7 \mathrm{f}$ & Not collected & $13.5 \mathrm{~d}$ & $85.3 \mathrm{c}$ & $10.3 \mathrm{c}$ \\
& Control HART & & & & & \\
& 89M & $75.9 \mathrm{~g}$ & Not collected & $12.5 \mathrm{c}$ & $135.2 \mathrm{e}$ & $17.2 \mathrm{~d}$ \\
& Isoline & $46.9 \mathrm{c}$ & Not collected & $10.3 \mathrm{~b}$ & $75.7 \mathrm{~b}$ & $10.7 \mathrm{c}$ \\
& HART 89M & $57.1 \mathrm{e}$ & Not collected & $9.4 \mathrm{a}$ & $99.7 \mathrm{~d}$ & $17 \mathrm{~d}$ \\
SEM & 0.59 & 0.05 & 0.22 & 2.06 & 0.42 \\
\hline
\end{tabular}

Table 8: Number of Meloidogyne incognita juveniles, egg mass and galling index of isoline and HART 89M (Trial 2)

\begin{tabular}{llccc} 
Time & Treatment & Galling index & Egg mass index & No of juveniles $\left(\mathbf{2 0 0 \mathbf { c m } ^ { 3 } )}\right.$ \\
\hline 90DAP & Isoline & $1.4 \mathrm{a}$ & $1.5 \mathrm{a}$ & $121.8 \mathrm{~b}$ \\
& HART 89M & $1.6 \mathrm{a}$ & $1.6 \mathrm{a}$ & $99.7 \mathrm{a}$ \\
\multirow{2}{*}{ 180DAP } & Isoline & $3.0 \mathrm{c}$ & $3.5 \mathrm{c}$ & $312.8 \mathrm{~d}$ \\
& HART 89M & $2.6 \mathrm{~b}$ & $2.4 \mathrm{~b}$ & $262.3 \mathrm{c}$ \\
SEM & & 0.08 & 0.05 & 2.04 \\
\hline
\end{tabular}

\section{DISCUSSION}

The present study demonstrated that $\mathrm{Bt}$ cotton expressing Cry1Ac and Cry2Ab2 protein was more susceptible to $M$. incognita than its isoline. HART 89M was moderately resistant compared with isoline, probably due to varietal differences. Otipa et al. (2009) also reported the same level of resistance in Kenyan cotton (Gossypium hirsutum) cultivars. At 180DAP, number of juveniles, galling and egg masss index were higher than at 90DAP due to the longer nematode reproduction time. M. incognita lays about $300-400$ eggs and it completes its lifecycle in 33-38 days (Banu, 2007). Galling index in cotton is a measurement of its response to infection by $M$. incognita and it is correlated to yield reduction in susceptible cultivars (Zhang et al., 2006). Large values of egg mass and galling index had a negative effect on plant height number of squares/bolls, plant, shoot and root weight across all treatment. However, fresh root weight in isoline increased at 180DAP. The increase in root weight in the infected plants was also observed by Setty and 
Wheeler, (1968) and they attributed this to the large amounts of tryptophan and other amino acids that are produced following infection. At the end of the growing season, Bt cotton had higher numbers of juveniles, galling and egg mass index compared with its isoline and this may be because isoline permitted penetration of infective juveniles and development of feeding sites but the nematodes did not develop into adult females resulting in a reduction of RKN reproduction (Jenkins et al., 1995). The high RKN reproduction in Bt cotton as shown by the galling index reduced cotton growth resulting in shorter plants which also weighed less than the isoline treatment. Hao et al. (2009) similarly reported that plant height and weight were negatively correlated with the galling index. Shoot weight of inoculated lettuce was reduced up 32\% after infection with M. hapla (Wong and Mai, 1973).

Stephan (1983) also reported a reduction in plant height, shoot and root weight in tomato after inoculation with different Meloidogyne species. Infection with $M$. incognita in Bt cotton may have resulted in a decrease in water movement from the roots to the leaves due to vascular disruption by giant cells. In a severe RKN attack, the vascular system is completely disrupted and numbers of rootlets are reduced thereby affecting nutrients and minerals uptake resulting in wilting and stunted growth (Kirkpatrick et al., 1991). Other secondary effects of RKN infection include reduced light interception which results in a reduction in photosynthetic efficiency.

Various studies have reported nematicidal activity of Bt proteins (Wei et al., 2003; Hoss et al., 2004). However, this was not observed in the current study despite the fact that Bt protein was detected in soil (at 180DAP) and roots (at 90 and 180DAP). The susceptibility of transgenic cotton to RKN has also been reported by Colyer et al. (2008) .. In other studies, purified Bt toxin did not have any toxic effect on RKN and inoculated plants had a higher galling index than the uninoculated plants (Devidas and Rehberger, 1997). Other authors

\section{ACKNOWLEDGEMENTS}

This is paper No. 29 of the BiosafeTrain project funded by the Danish International Development Agency (DANIDA). The authors thank the Kenya Agricultural Research Institute, National Agricultural Research Laboratories (KARI-NARL) for providing laboratory

\section{REFERENCES}

Banu J, 2007. Nematode pests of cotton Model training course on cultivation of long staple cotton. have reported toxic effects of $\mathrm{Bt}$ protein on Meloidogyne spp. Chahal and Chahal (1993) reported a reduction in reproduction of $M$. javanica and $M$. incognita following application of Bacillus formulations. Dhawan et al. (2004) demonstrated that Bacillus spp could reduce the mobility of $M$. incognita juveniles. Similarly, root galling and reproduction of $M$. incognita race 3 on chick pea was reduced after treatment with Bacillus species (Siddiqui and Mahamood 1983) and inhibition of nematode penetration in tomato was also observed (Oka et al., 1993).

Cry proteins or pleiotropic effects resulting from genetic transformation may have been responsible for the susceptibility of $\mathrm{Bt}$ cotton to $M$. incognita since alterations in the host plant may change the level of resistance, nematode attraction and feeding behaviour. Bendezu and Starr (2003) identified two types of RKN resistance in plants including preinfection resistance which is due to the presence of compounds in the roots that inhibits penetration of RKN, and the post infection resistance where the nematodes enter the roots but they do not develop into mature females. Resistant plants show an upregulation of the 14KDA polypeptide MIC3 defence genes which accumulates within the immature galls (Callahan et al., 1997). The upregulation of these genes may explain the moderate resistance observed in HART 89M.

The observed reaction of $\mathrm{Bt}$ cotton in the greenhouse should be confirmed in the field since $M$. incognita may be affected by other environmental factors. According to Vrain (1977), Meloidogyne infectivity is influenced by soil texture, temperature, moisture, aeration and density and it is also a function of the distance that the juvenile has to travel in order to penetrate the roots. The study has however demonstrated that Bt cotton is susceptible to $M$. incognita and it would be important to integrate nematode management practices such as the use of organic amendments and nematicides with other cultural practices in Kenyan Bt cotton agroecosystems.

space and equipments. We acknowledge Mette Vesteergard for assistance in nematode identification, Maurice Okomo and Mary Ndunguli for technical support and Elias Thuranira for assistance in data analysis. 
ELS Central institute for cotton research, Regional station, Coimbatore. www.cicrorgin/pdf/ELS/prot5pdf

Bendezu IF. and Starr J, 2003. Mechanism of resistance to Meloidogyne arenaria in the peanut cultivar. Journal of nematology 35 : $115-118$

Callahan F, Jenkins J, Creech R, Lawrence G, 1997. Changes in cotton root proteins correlated with resistance to root knot nematode development. Journal of Cotton Science 1: 3847.

Chahal PPK. and Chahal VPS, 1993. Effect of thuricide on the hatching of eggs root-knot nematode, Meloidogyne incognita. Current Nematology 4: 247.

Colyer PD, Kirkpatrick TL, Caldwell WD, Vernon, PR, 2008. Root-knot nematode reproduction and root galling severity on related conventional and transgenic cotton cultivars. Journal of Cotton Science 4: 232-236.

Dawar S, Tariq M, Zaki, MJ 2008. Application of Bacillus species in control of Meloidogyne javanica treub chitwood on cowpea and mash bean. Pakistan Journal of Botany 40: 439-444.

Devidas P. and Rehberger LA, 1992. The effect of exotoxin thuringiensis from Bacillus thuringiensis on Meloidogyne incognita and Caenorhabditis elegans. Plant and Soil 145: $115-120$

Dhawan, SC, Sarvjeet K, Aqbal S, 2004. Effect of Bacillus thuringiensis on the mortality of rootknot nematode, Meloidogyne incognita. Indian Journal of Nematology 34: 98-99.

Hao JJ, Yang ME, Davis RM, 2009. Effect of soil inoculum density of Fusarium oxysporum $f$ spvasinfectum Race 4 on disease development in Cotton. Plant Disease 93: 1324-1328

Holbrook CC, Knauft DA, Dickson DW, 1983. A technique for screening peanut for resistance to Meloidogyne arenaria. Plant Disease 67: 957-958.

Hoss S, Arndt M, Baumgarte, S, Tebbe CC, 2004. Effects of soil from experimental fields with transgenic corn on the nematode Caenorhabditis elegans. Abstract from Society of Environmental Toxicology and Chemistry, 14th Annual Meeting, Prague.

Jenkins JN, Creech RG, Tang B, Lawrence GW, McCarty JC, 1995. Cotton resistance to root- knot nematode: II Post penetration development. Crop Science 35: 369-373.

Kirkpatrick TL, Oosterhuis DM, Wullschleger SD, 1991. Interaction of Meloidogyne incognita and water stress in two cotton cultivars Journal of Nematology 23: 462-467.

Li XQ, Wei JZ, Tan A, Aroian RV, 2007. Resistance to root-knot nematode in tomato roots expressing a nematicidal Bacillus thuringiensis crystal protein. Plant biotechnology journal 5: 455464.

Otipa MJ, Kimenju JW, Mureithi JG, Kyalo G, 2009. Potential of rotation crops in managing root knot Meloidogyne spp nematodes in tomato. African Journal of Horticultural Science 2: 111123.

Phap $\mathrm{P}$, Xuan $\mathrm{H}$, Sudhakar D, Balasubramanian $\mathrm{P}$, 2010. Engineering resistance in brinjal against nematode Meloidogyne incognita using cry1 $\mathrm{Ab}$ gene from Bacillus thuringiensis Berliner. Proceedings of the 3rd International Conference on the Development of BME in Vietnam, 11-14th Jan 2010.

Prasad S, Tilak K, Gollakota RG, 1972. Role of Bacillus thuringiensis var thuringiensis on the larval survivability and egg hatching of Meloidogyne spp The causative agent of root-knot disease. Journal of Inverterbrate pathology 20: 377 378.

Senthilkumar P, Ramakrishan S, Prabhu S, 2008. Reaction of Bt and popular varieties of cotton to Rotylenchulus reniformis. Indian journal of nematology 38: 127-130.

Setty KGH. and Wheeler AW, 1968. Growth substances in roots of tomato Lycopersicon esculentum Mill infected with root-knot nematodes Meloidogyne spp. Annals of Appllied Biology 61: 495-501.

Sharma RD, 1994. Bacillus thuringiensis a biocontrol agent of Meloidogyne incognita on barley. Nematologia Brasileria 18: 79-84.

Sheikh LI, Dawa, S, Zaki MJ, Ghaffar A, 2006. Efficacy of Bacillus thuringiensis and Rhizobium meliloti with nursery fertilizers in the control of root infecting fungi on mung bean and okra plants. Pakisitan Journal of Botany 38: 465473.

Siddiqui ZA. and Mahmood I, 1999. Role of bacteria in the management of plant parasitic nematodes: a review. Bioresource Technology 69: 167179. 
Srivastava RK, 1973. Effect of exotoxin of Bacillus thuringiensis var thuringiensis on root knot nematode. MSc thesis submitted to Pant University of Agriculture and Technology, Pantnagar.

Stephan ZA, 1983. The effect of different densities of Meloidogyne ardenensis and of three population of M. hapla on the growth of tomato at four soil temperatures. Nematol Medeit 11, 93-100.

Vrain T, 1977. A technique for the collection of larvae of Meloidogyne spp and a comparison of eggs and larvae as inocula. Journal of nematology 9: 250-255.

Wei JZ, Hale K, Carta L, Platzer E, Wong C, Fang SC, Aroian RV, 2003. Bacillus thuringiensis crystal proteins that target nematodes. Proceedings of the National Academy of Sciences USA 100: $2760-2765$.

Whitehead AG. and Hemming JR, 1965. A comparison of some quantitative methods of extracting small vermiform nematodes from soil Nematology 4: 96-100.

Wong TK. and Mai WF, 1973. Pathogenicity of Meloidogyne hapla to lettuce as affected by inoculum level, plant age and temperature. Journal of Nematology 5: 126-129.

Wubben MJ, Callahan FE, Hayes RW, Jenkins JN, 2008. Molecular characterization and temporal expression analyses indicate that the MIC Meloidogyne Induced Cotton gene family represents a novel group of root-specific defense-related genes in upland cotton Gossypium hirsutum L. Planta 228: 111-123.

Zhang J, Waddell C, Gopalan C, Potenza C, Cantrell R, 2006. Relationships between root-knot nematode resistance and plant growth in upland cotton: Galling Index as a Criterion. Crop science 46:1581-1586

Zuckermann BE, Dicklow MB, Ascosta N, 1993. A strain of Bacillus thuringiensis for the control of plant parasitic nematodes. Biocontrol Science and Technology 3: 41-46. 